\title{
Asupan zat gizi, status gizi dan motivasi serta hubungannya dengan produktivitas pekerja perempuan pada bagian pencetakan di Pabrik Bakpia Pathuk 25 Yogyakarta
}

\author{
Rina Kusriyana ${ }^{1}$, Siti Helmyati², R. Dwi Budiningsari ${ }^{3}$
}

\begin{abstract}
Background: Employees' productivity is closely related with nutritional condition. Nutritional condition can be physically assessed by determining nutrition status. One's nutrition status is directly influenced by nutrient intake. However, health and nutrition status of an employee in general have not got proper attention that lead to decreasing productivity. Productivity is not only influenced by nutrition status but also by psychological factor that involves motivation.

Objectives: To identify association between nutrient intake, nutrition status and motivation and productivity of female workers at production department of Bakpia Pathuk 25 Factory Yogyakarta.

Method: The study was a survey that used cross sectional design. Subject of the study were female workers at production department as many as 40 people taken through proportional stratified random sampling technique. Data of subject assessed were nutrient intake (energy, carbohydrate, fat, protein, and Fe), nutrition status, motivation, and productivity. Nutrient intake was assessed using food recall 24 hours within 4 days, nutrition status was specified using anthropometric approach using body mass index (weight/height), motivation was assessed through motivation questionnaire and productivity through quantity of production (raw bakpia) produced by the worker at a time observation (44 minutes for workers at crust production and 1 hour for workers at filling department) within 3 times observation.

Result: The result of linear regression analysis showed that association between nutrient intake (energy, carbohydrate, fat, protein and $\mathrm{Fe}$ ), nutrition status and productivity was $r<0.25$ and $p>0.05$ whereas between motivation and productivity was $r=0.901 ; R 2=0.812$; and $p=0.000$ for variables of wages, intake of energy, Fe and motivation and productivity.

Conclusion: There was no significant association between nutrient intake (energy, carbohydrate, fat, protein and Fe) and nutrition status and productivity; there was significant association between motivation and productivity. Concurrently only motivation had significant association with productivity.
\end{abstract}

KEY WORDS nutrient intake, nutrition status, motivation, productivity, female workers

\section{PENDAHULUAN}

Menurut laporan World Economic Forum tahun 2003-2004, daya saing dalam hal sumber daya manusia Indonesia menduduki ranking ke-37 pada tahun 1999 , turun menjadi ranking ke-44 pada tahun 2000 , menurun lagi ke urutan 49 pada tahun 2001, menurun drastis pada tahun 2002 ke urutan 69 dan pada tahun 2003 mencapai peringkat terendah menjadi 72 . Hal ini menunjukkan bahwa produktivitas kerja di Indonesia menurun drastis terutama bila dibandingkan dengan negara-negara ASEAN (1).

Produktivitas merupakan akar penentu tingkat daya saing, baik pada tingkat individu, perusahaan, industri, maupun pada tingkat negara. Peningkatan produktivitas terutama faktor total, baik tingkat makro, sektoral industri, perusahaan, dan individu sangat menentukan kemampuan daya saing perusahaan pada tingkat dalam negeri, regional, maupun global. Peningkatan produktivitas pada tingkat individu menempati posisi yang sangat penting (1).

Berdasarkan data Badan Pusat Statistik (BPS) tahun 2002, pekerja Indonesia di bidang industri pengolahan mencapai 7.941 .301 orang yang terdiri dari $63,63 \%$ pekerja laki-laki dan $36,37 \%$ pekerja perempuan sedangkan pada tahun 2006 pekerja laki-laki yang bekerja di industri pengolahan mencapai $44,03 \%$ dan pekerja perempuan mencapai 55,97\%. Tingkat Partisipasi Angkatan Kerja (TPAK) pada perempuan juga mengalami peningkatan, yaitu dari 49,23\% pada tahun 2004 menjadi 50,65\% pada tahun 2005. Peningkatan jumlah pekerja ini berakibat positif pada pertambahan tenaga produktif. Namun, status kesehatan dan gizi pekerja pada umumnya belum mendapat perhatian yang berakibat pada penurunan produktivitas kerja dan biaya produksi menjadi tidak efisien (2).

Meningkatnya pekerja perempuan memerlukan perhatian khusus karena kebutuhan zat besi perempuan rata-rata dua kali daripada kebutuhan laki-laki. Perempuan bekerja relatif lebih lama daripada laki-laki. Waktu istirahat untuk pemulihan tenaga pada perempuan relatif lebih pendek, dan upah yang diterima oleh pekerja perempuan relatif lebih kecil karena pendidikan perempuan lebih rendah (3).

Penelitian ini dilakukan di Pabrik Bakpia Pathuk 25. Pabrik ini memproduksi bakpia yang merupakan salah satu

\footnotetext{
UPTD Puskesmas Jatinegara, Jl. Raya Jatinegara Tegal, e-mail: finzagina@yahoo.com

2 Program Studi Gizi Kesehatan Fakultas Kedokteran UGM, JI. Farmako, Sekip Utara, Yogyakarta 55281, e-mail: siti_helmyati@yahoo.com

3 Magister Gizi dan Kesehatan Fakultas Kedokteran UGM, JI. Farmako, Sekip Utara, Yogyakarta 55281, e-mail: budiningsari25@yahoo.com
} 
makanan khas Yogyakarta. Produk bakpia yang dihasilkan memiliki berbagai macam rasa, di antaranya rasa kacang hijau, nanas, coklat, dan keju. Proses pembuatan bakpia meliputi beberapa tahap, yaitu pembuatan adonan kulit, pembuatan isi/kumbu, pencetakan, pemanggangan dan pendinginan.

Pekerja di pabrik Bakpia Pathuk 25 sebagian besar adalah perempuan. Pekerja perempuan adalah salah satu kelompok yang sangat rawan terhadap masalah kurang energi protein dan anemia. Pabrik Bakpia Pathuk 25 juga menyelenggarakan makan siang bagi karyawannya yang proses pengolahannya dilakukan oleh karyawan pabrik. Pabrik ini juga masih menggunakan sistem manual sehingga peneliti akan lebih mudah untuk menentukan produktivitas dan di pabrik Bakpia Pathuk 25 belum pernah diadakan penelitian yang sejenis.

Secara umum diketahui bahwa status gizi berpengaruh terhadap produktivitas kerja. Rendahnya berat badan menurut tinggi badan (BB/TB), lingkar lengan atas (LILA) yang kecil, indeks mass tubuh (IMT) dan tinggi badan yang kurang berhubungan dengan rendahnya produktivitas pada pekerja berat. Penelitian di Kudus menunjukkan bahwa pekerja pelinting rokok di Kudus adalah pekerja yang memiliki IMT 18,5 dan < 17,0 memiliki produktivitas $5,1 \%$ dan $6,8 \%$ lebih rendah daripada pekerja yang memiliki IMT 18,5 - 22,5.

Tujuan penelitian ini adalah untuk mengetahui hubungan asupan zat gizi, status gizi dan motivasi dengan produktivitas pekerja perempuan di bagian percetakan pabrik Bakpia Pathuk 25 Yogyakarta, selain itu juga untuk mengetahui hubungan antara asupan zat gizi (energi, karbohidrat, lemak, protein dan zat besi dengan produktivitas.

\section{BAHAN DAN METODE}

Jenis penelitian yang dilakukan adalah observasional (non-eksperimental) dengan rancangan cross sectional. Penelitian yang dilaksanakan di pabrik Bakpia Pathuk 25 Yogyakarta. Waktu penelitian bulan Agustus-September 2006. Populasi penelitian adalah seluruh pekerja perempuan pada bagian pencetakan yang terdiri dari bagian pembuatan kulit dan pencetakan yang ada di pabrik Bakpia Pathuk 25 Yogyakarta yang berjumlah 65 orang.

Subjek penelitian adalah seluruh pekerja perempuan pada bagian pencetakan yang memenuhi kriteria inklusi yang meliputi: perempuan berusia 20-50 tahun, berbadan sehat dan tidak menderita penyakit kronis dan infeksi saat dilakukan penelitian, telah bekerja selama minimal 1 tahun, bersedia menjadi subjek penelitian, serta dapat membaca dan menulis.

Subjek didapatkan dengan teknik proportional stratified random sampling. Data asupan zat gizi (energi, protein, lemak, karbohidrat, dan zat besi) diperoleh dengan cara wawancara dengan metode recall 24 jam selama 4 hari. Data status gizi diperoleh dengan mengukur berat badan menggunakan indikator IMT $\left(\mathrm{BB} / \mathrm{TB}^{2}\right)$. Berat badan diukur dengan menggunakan timbangan injak dengan tingkat ketelitian 0,1 kg. Penimbangan dilakukan pada pagi hari, sebelum sarapan. Subjek berpijak pada timbangan, tanpa menggenggam atau menyentuh apapun, alas kaki sepatu dilepas. Tinggi badan diukur dengan microtoise dengan ketelitian $0,1 \mathrm{~cm}$. Subjek berdiri tegak tanpa alas kaki sejajar alat pengukur, tumit, bokong, kepala bagian belakang menempel pada dinding, dalam sikap tegak memandang ke depan.

Data tentang motivasi diperoleh dengan angket motivasi yang berisi butir pertanyaan yang sudah diuji validitas dan reliabilitasnya. Berdasarkan hasil pengujian validitas butir pertanyaan pada angket motivasi diperoleh bahwa dari keseluruhan 25 butir, dinyatakan gugur sebanyak 8 butir sehingga selanjutnya digunakan hanya 17 butir. Butir pertanyaan dalam angket motivasi dinyatakan gugur bila $r<0,361$ dan dinyatakan valid bila $r>0,361$. Hasil pengujian reliabilitas angket motivasi diperoleh nilai cronbach alpha 0,893 (Cronbach alpha > 0,361) maka dapat disimpulkan bahwa angket tersebut andal untuk digunakan.

Angket motivasi tersebut dibuat berdasarkan teori kebutuhan dari Maslow yang menyatakan bahwa kebutuhan manusia terdiri dari kebutuhan fisik, keamanan, sosial, penghargaan dan aktualisasi diri (11). Produktivitas diukur dengan jumlah produksi (kulit bakpia/bakpia mentah) yang dicapai oleh pekerja selama satuan waktu pengamatan (44 menit untuk pekerja pada bagian pembuatan kulit dan 1 jam untuk pekerja pada bagian pengisian) selama 3 kali pengamatan.

Selain data-data tersebut, dalam penelitian ini juga digali data tentang identitas subjek, data demografi (usia, pendidikan, status perkawinan dan jumlah tanggungan keluarga) serta data sosial ekonomi (masa kerja dan upah/ gaji) melalui wawancara dan data tentang gambaran umum pabrik diperoleh melalui buku pabrik dan wawancara. Datadata yang telah diperoleh kemudian dianalisis secara analitik dengan chi square, regresi linier dan regresi linier ganda.

\section{HASIL DAN BAHASAN}

Diperoleh sebanyak 40 orang subjek yang memenuhi kriteria inklusi dan eksklusi. Sebagian besar subjek (75,0\%) berusia 20-30 tahun dan masa kerja yang paling dominan adalah lebih dari 3 tahun (70,0\%). Dilihat dari latar belakang pendidikan, sebanyak $47,5 \%$ dari subjek adalah tamatan SMA serta sisanya adalah tamatan SD dan SMP. Upah/gaji yang diterima oleh subjek, sebagian besar $(62,5 \%)$ sudah sesuai dengan UMR tahun 2006 yaitu sebesar Rp 460.000,00 per bulan atau Rp 15.300,00 per hari. Tidak ada perbedaan 
yang signifikan karakteristik subjek antara yang produktif dan tidak produktif $(P>0,05)$ kecuali dalam hal upah/gaji $(p<0.05)$ seperti yang ditampilkan dalam Tabel 1. dihasilkan oleh masing-masing tenaga kerja perempuan pada bagian pengisian selama 1 jam pengamatan dalam 3 hari pengukuran.

Tabel 1. Distribusi subjek berdasarkan umur, masa kerja, tingkat pendidikan, upah/gaji, jumlah tanggungan keluarga, status perkawinan dan produktivitas

\begin{tabular}{|c|c|c|c|c|c|c|c|c|}
\hline \multirow{3}{*}{ Karakteristik } & \multicolumn{4}{|c|}{ Tingkat Produktivitas } & & & \multirow{3}{*}{$\chi^{2}$} & \multirow{3}{*}{$\begin{array}{c}P \\
\text { value }\end{array}$} \\
\hline & \multicolumn{2}{|c|}{ Produktif } & \multicolumn{2}{|c|}{ Kurang produktif } & \multicolumn{2}{|c|}{ Total } & & \\
\hline & $\mathbf{n}$ & $\%$ & $\mathbf{n}$ & $\%$ & $\mathrm{n}$ & $\%$ & & \\
\hline \multicolumn{9}{|l|}{ Usia ${ }^{b}$} \\
\hline 20-30 tahun & 13 & 43,3 & 17 & 56,7 & 30 & 100 & 4,444 & 0,11 \\
\hline $31-40$ tahun & 7 & 75 & 2 & 25 & 8 & 100 & & \\
\hline$\geq 41$ tahun & 0 & 0 & 2 & 100 & 2 & 100 & & \\
\hline \multicolumn{9}{|l|}{ Masa kerja ${ }^{b}$} \\
\hline$<3$ tahun & 12 & 42,9 & 16 & 57,1 & 28 & 100 & 2,478 & 0,48 \\
\hline $3-5$ tahun & 4 & 50 & 4 & 50 & 8 & 100 & & \\
\hline $6-8$ tahun & 2 & 100 & 0 & 0 & 2 & 100 & & \\
\hline$\geq 9$ tahun & 1 & 50,0 & 1 & 50,0 & 3 & 100 & & \\
\hline \multicolumn{9}{|l|}{ Tingkat pendidikan ${ }^{b}$} \\
\hline SD & 2 & 66,7 & 1 & 33,3 & 3 & 100 & 0,709 & 0,70 \\
\hline SMP & 9 & 50 & 9 & 50 & 18 & 100 & & \\
\hline SMA & 8 & 42,1 & 11 & 57,9 & 19 & 100 & & \\
\hline \multicolumn{9}{|l|}{ Upah/gajia } \\
\hline$\geq$ Rp15.300,00 & 16 & 64 & 9 & 36 & 25 & 100 & 5,621 & $0,02^{*}$ \\
\hline$<$ Rp15.300,00 & 3 & 20 & 12 & 80 & 15 & 100 & & \\
\hline \multicolumn{9}{|l|}{$\begin{array}{l}\text { Jumlah tanggungan } \\
\text { keluarga }^{b}\end{array}$} \\
\hline$\leq 1$ & 9 & 50,0 & 9 & 50,0 & 18 & 100 & 0,709 & 0,70 \\
\hline $2-4$ & 8 & 42,1 & 11 & 57,9 & 19 & 100 & & \\
\hline$\geq 5$ & 2 & 66,7 & 1 & 33,3 & 4 & 100 & & \\
\hline \multicolumn{9}{|l|}{ Status perkawinan ${ }^{a}$} \\
\hline Menikah & 13 & 50 & 13 & 50 & 26 & 100 & 0,186 & 0,67 \\
\hline Belum menikah & 6 & 42,9 & 8 & 57,1 & 14 & 100 & & \\
\hline
\end{tabular}

Keterangan:

${ }^{a} \mathrm{p}$ (chi square)

${ }^{\mathrm{b}} \mathrm{p}$ (Fisher exact test)

* Bermakna $(p<0,05)$

Tabel 1 menunjukkan bahwa usia, masa kerja, tingkat pendidikan, jumlah tanggungan keluarga dan status perkawinan tidak mempunyai hubungan bermakna dengan tingkat produktivitas. Hal tersebut berarti tidak ada perbedaan proporsi yang bermakna antara tingkat produktivitas pada kelompok usia, masa kerja, tingkat pendidikan, jumlah tanggungan keluarga dan status perkawinan subjek kecuali upah/gaji subjek.

\section{Produktivitas}

Produktivitas pekerja dalam penelitian ini dilihat berdasarkan jumlah rata-rata kulit bakpia yang dihasilkan oleh masing-masing tenaga kerja perempuan pada bagian pembuatan kulit selama 44 menit pengamatan dalam 3 hari pengukuran atau jumlah rata-rata bakpia mentah yang
Berdasarkan penelitian, rata-rata produktivitas subjek dalam penelitian ini adalah 203,55 satuan produksi dengan simpangan baku sebesar 64,902. Berdasarkan hasil rata-rata produktivitas tersebut, subjek penelitian dapat diklasifikasikan menjadi dua, yaitu subjek yang produktif dan subjek yang kurang produktif. Subjek penelitian termasuk dalam kategori produktif jika jumlah produksinya $\geq 203,55$ satuan produksi sedangkan bila jumlah produksinya $<203,55$ satuan produksi maka subjek tersebut termasuk dalam kategori kurang produktif. Subjek penelitian yang produktif sebanyak 19 orang $(47,5 \%)$.

\section{Asupan Zat Gizi}

Berdasarkan hasil penelitian pada Tabel 2, rata-rata asupan zat gizi subjek termasuk rendah. 
Tabel 2. Distribusi asupan zat gizi subjek

\begin{tabular}{lcc}
\hline \multicolumn{1}{c}{ Variabel } & Mean \pm SD & $\begin{array}{c}\text { Minimal- } \\
\text { maksimal }\end{array}$ \\
\hline Energi (kkal) & $1264,415 \pm 214,217$ & $814,4-1786,6$ \\
Protein $(\mathrm{g})$ & $39,535 \pm 9,707$ & $20,5-62,7$ \\
Lemak $(\mathrm{g})$ & $27,985 \pm 7,367$ & $11,1-43,8$ \\
Karbohidrat $(\mathrm{g})$ & $217,205 \pm 49,047$ & $156,3-433,0$ \\
Zat besi $(\mathrm{mg})$ & $7,718 \pm 4,493$ & $3-29,4$ \\
\hline
\end{tabular}

\section{Status Gizi}

Sebagian besar subjek dalam penelitian ini, status gizinya termasuk dalam kategori normal.Data selengkapnya disajikan pada Tabel 3.

Tabel 3. Distribusi data antropometri subjek

\begin{tabular}{lcc}
\hline \multicolumn{1}{c}{ Variabel } & Mean \pm SD & Minimal-maksimal \\
\hline Berat badan $(\mathrm{kg})$ & $46,553 \pm 5,779$ & $33,10-61,50$ \\
Tinggi badan $(\mathrm{m})$ & $1,498 \pm 0,060$ & $1,34-1,62$ \\
IMT $(\mathrm{m} / \mathrm{kg} 2)$ & $20,757 \pm 2,335$ & $15,53-27,25$ \\
\hline
\end{tabular}

Dari data penelitian tersebut, selain dapat diketahui rata-rata IMT subjek, juga dapat diketahui status gizi subjek berdasarkan IMT. Klasifikasi status gizi berdasarkan IMT adalah underweight sebanyak 16 persen, normal sebanyak $72,5 \%$, overweight sebanyak $5 \%$ dan obese sebanyak $7,5 \%$.

\section{Motivasi}

Berdasarkan data penelitian, selain diketahui rata-rata skor motivasi subjek adalah 58,88 $( \pm 6,75)$. Berdasarkan hasil penelitian ini juga dapat diketahui klasifikasi skor motivasi subjek yang dibandingkan dengan skor rata-rata. Motivasi subjek termasuk dalam kategori tinggi jika skor yang diperoleh lebih tinggi atau sama dengan rata-rata $(\geq 58,875)$ dan motivasi subjek termasuk dalam kategori rendah jika skor yang diperoleh lebih rendah dari rata-rata $(<58,875)$. Berdasarkan rata-rata tersebut, terdapat 22 orang $(55,0 \%)$ subjek yang motivasinya termasuk dalam kategori tinggi dan sebanyak 18 orang $(45,0 \%)$ yang motivasinya rendah.

\section{Hubungan antara asupan zat gizi dengan produktivitas}

Analisis regresi linier digunakan untuk mengetahui hubungan antara asupan zat gizi (energi, protein, lemak, karbohidrat dan zat besi) dengan produktivitas. Hasil analisis untuk masing-masing variabel tersebut dapat dilihat pada Tabel 4.

Berdasarkan Tabel 4 menunjukkan bahwa hubungan antara variabel asupan energi, protein, lemak, karbohidrat, dan zat besi dengan produktivitas menunjukkan hubungan yang lemah $(r \leq 0,25)$. Hasil uji statistik didapatkan
Tabel 4. Analisis korelasi dan regresi asupan energi, protein, lemak, karbohidrat dan zat besi dengan produktivitas

\begin{tabular}{lccc}
\hline \multicolumn{1}{c}{ Variabel } & $\mathbf{r}$ & $\mathbf{R}^{\mathbf{2}}$ & $\mathbf{P}$ value \\
\hline Asupan energi & 0,225 & 0,051 & 0,16 \\
Asupan protein & 0,122 & 0,015 & 0,454 \\
Asupan lemak & 0,144 & 0,021 & 0,375 \\
Asupan karbohidrat & 0,090 & 0,008 & 0,579 \\
Asupan zat besi & 0,231 & 0,053 & 0,151 \\
\hline
\end{tabular}

tidak ada hubungan yang bermakna antara asupan energi, protein, lemak, karbohidrat dan zat besi dengan produktivitas $(p>0,05)$.

Tidak ada hubungan bermakna antara asupan energi dan produktivitas disebabkan pada penelitian ini seluruh subjek dalam penelitian ini berjenis kelamin perempuan. Hal tersebut sesuai dengan hasil penelitian yang menyatakan bahwa ada hubungan antara asupan energi dengan produktivitas akan tetapi hanya berlaku pada laki-laki saja, tidak berlaku pada perempuan (12). Selain itu, penelitian di Provinsi Jawa Tengah dan Sumatra Barat menemukan bahwa asupan energi juga hanya berpengaruh pada tingkat produktivitas pekerja yang terampil dan tidak menderita anemia. Pada pekerja yang anemia, asupan energi tidak berpengaruh. Namun, dalam penelitian ini tidak diketahui status anemia pekerja (13).

Tidak ada hubungan bermakna antara asupan protein dengan dengan produktivitas. sesuai dengan penelitian di Sleman yang menyatakan bahwa tidak ada hubungan yang bermakna antara asupan protein dengan produktivitas (7). Tidak adanya hubungan antara asupan protein dengan produktivitas pada penelitian ini juga dapat disebabkan oleh kelemahan penelitian ini yaitu dalam melakukan recall menggunakan standar ukuran makan siang karyawan di pabrik sehingga terjadi bias underestimate.

Menurut hasil penelitian di Provinsi Jawa Tengah dan Sumatra Barat, asupan protein juga hanya berpengaruh pada tingkat produktivitas pekerja terampil yang tidak menderita anemia (13). Pada pekerja yang anemia, asupan protein tidak berpengaruh. Namun, dalam penelitian ini tidak diketahui status anemia pekerja.

Berdasarkan hasil analisis didapatkan tidak ada hubungan yang bermakna antara asupan karbohidrat dengan produktivitas. Asupan zat gizi pekerja yang paling utama adalah asupan karbohidrat untuk energi kerja otot (14). Fungsi utama karbohidrat adalah menyediakan energi bagi tubuh. Karbohidrat merupakan sumber utama energi bagi penduduk di seluruh dunia, karena banyak terdapat di alam dan harganya relatif murah.

Berdasarkan hasil analisis didapatkan tidak ada hubungan yang bermakna antara asupan zat besi dengan produktivitas kerja. Hasil penelitian ini berbeda dengan penelitian di antara pekerja Indian yang menyatakan ada hubungan antara asupan zat besi dengan produktivitas 
(15). Tidak adanya hubungan antara asupan zat besi dengan produktivitas pada penelitian ini disebabkan asupan zat besi subjek dalam penelitian ini masih jauh di bawah kebutuhan minimumnya sehingga variasinya tidak berpengaruh terhadap produktivitas.

Tidak adanya hubungan antara asupan zat gizi dengan produktivitas pada penelitian ini juga berhubungan dengan kelemahan pada penelitian ini yaitu dalam melakukan recall, untuk membantu subjek dalam mengingat porsi makanan yang dikonsumsi dengan menggunakan standar makan siang yang diselenggarakan oleh pabrik sehingga terjadi bias underestimate.

\section{Hubungan antara status gizi dengan produktivitas}

Hubungan antara status gizi dan produktivitas menunjukkan hubungan yang lemah $(r=0,891)$ dan berpola positif artinya semakin tinggi motivasi pekerja semakin bertambah pula produktivitasnya. Hasil uji statistik didapatkan ada hubungan yang bermakna antara motivasi dan produktivitas $(p<0,01)$.

Hasil analisis regresi linier pada penelitian ini didapatkan nilai $r=0,042$ dan $p=0,796(p>0,05)$. Hal ini berarti tidak ada hubungan yang bermakna antara status gizi dengan produktivitas kerja.

Hasil penelitian ini sesuai dengan penelitian mengenai hubungan antara IMT dengan produktivitas di 6 negara (Gambia, Ghana, Pakistan, Kenya, Philipina dan Guatemala) yang menyatakan bahwa tidak ada hubungan antara IMT dengan produktivitas (16). Penelitian lain yang mendukung hasil dari penelitian ini adalah penelitian mengenai hubungan antara IMT dengan produktivitas kerja pada pelinting rokok di Kudus (5).

Tenaga kerja dalam penelitian ini adalah tenaga kerja yang bekerja dengan mempergunakan keterampilan. Hal ini didukung hasil penelitian yang yang menyatakan bahwa produktivitas tenaga kerja yang mempergunakan keterampilan tidak hanya dipengaruhi oleh status gizi, tapi juga dipengaruhi oleh faktor lain (17).

Hal tersebut juga sejalan dengan penelitian yang dilakukan di Provinsi Jawa Tengah dan Sumatra Barat yang menyatakan bahwa status gizi yang dicerminkan dengan indeks berat-tinggi badan hanya berpengaruh pada pekerja kasar dan tidak berpengaruh pada jenis pekerjaan terampil yang lebih membutuhkan faktor ketelitian dan ketepatan (13).

Namun, penelitian yang menyatakan bahwa ada hubungan antara status gizi yang dicerminkan oleh berat badan terhadap tinggi badan (BB/TB) dan kadar hemoglobin terhadap produktivitas kerja. Perbedaan hasil penelitian ini disebabkan adanya perbedaan standar yang digunakan dalam menentukan status gizi (6).

\section{Hubungan antara motivasi dan produktivitas}

Berdasarkan analisis regresi linier pada penelitian ini diperoleh bahwa antara motivasi dengan produktivitas kerja ada hubungan positif yang kuat $(r=0,891)$ dan bermakna $p<0,001$. Hal ini berarti semakin tinggi motivasi kerja tenaga kerja, semakin tinggi pula produktivitasnya. Nilai koefisien dengan determinasi $(R)$ adalah 0,80 artinya persamaan garis regresi yang diperoleh dapat menerangkan $80,0 \%$ dari variasi produktivitas, sedangkan sisanya dari variabel lain. Hal ini menjelaskan bahwa pemberian motivasi kepada karyawan ternyata sangat mempengaruhi produktivitas kerja karyawan.

Motivasi adalah daya pendorong yang mengakibatkan seseorang anggota organisasi mau dan rela menyerahkan kemampuan dalam bentuk keahlian atau keterampilan, tenaga dan waktunya untuk menyelenggarakan berbagai kegiatan yang menjadi tanggungjawabnya dan menunaikan kewajibannya dalam rangka mencapai tujuan dan berbagi sasaran organisasi yang telah ditentukan (18).

Angket motivasi dalam penelitian ini didasarkan pada teori kebutuhan dari Maslow yang terdiri dari kebutuhan fisik, kebutuhan akan rasa aman, rasa memiliki, penghargaan dan aktualisasi diri. Menurut hasil penelitian pada para pekerja di proyek konstruksi, kebutuhan fisik, rasa aman dan rasa memiliki adalah motivator untuk meningkatkan produktivitas dalam jangka pendek, namun pemenuhan tersebut harus terpuaskan dahulu sebelum pemenuhan terhadap motivator jangka panjang (11).

Hasil penelitian ini sesuai dengan hasil penelitian di Kabupaten Karanganyar dan di Surakarta (19). Penelitian di Karanganyar tentang hubungan antara motivasi, pengawasan dan budaya kerja dengan produktivitas kerja karyawan Perusahaan Daerah Bank Perkreditan Rakyat, Badan Kredit Desa menyatakan bahwa motivasi mempunyai pengaruh yang positif dan bermakna terhadap produktivitas (19). Penelitian di Surakarta menemukan bahwa ternyata variabel motivasi kerja terhadap produktivitas kerja pengaruhnya lebih besar daripada variabel kepuasan kerja (9).

\section{Hubungan antara upah/gaji, asupan energi, asupan protein dan motivasi dengan produktivitas}

Hasil analisis lebih lanjut menggunakan analisis regresi linier ganda menunjukkan bahwa secara bersamasama variabel upah/gaji, asupan energi, asupan zat besi dan motivasi mempunyai hubungan yang bermakna dengan produktivitas di mana $r=0,894 ; R 2=0,80$ dan $p=$ 0,01 ). Sumbangan efektif faktor upah/gaji, asupan energi, asupan zat besi, motivasi dan produktivitas dapat dilihat pada tabel di bawah ini. 
Tabel 5. Nilai koefisien B dan sumbangan efektif faktor gaji, asupan energi, asupan zat besi, dan motivasi terhadap produktivitas

\begin{tabular}{lccccc}
\hline \multicolumn{1}{c}{ Variabel } & Koef B & $\begin{array}{c}\text { Sumbangan } \\
\text { efektif (\%) }\end{array}$ & $\mathbf{r}$ & $\mathbf{R}^{\mathbf{2}}$ & $\begin{array}{c}\mathbf{P} \\
\text { value }\end{array}$ \\
\hline $\begin{array}{l}\text { Gaji } \\
\text { Asupan }\end{array}$ & 0,005 & 1,1 & 0,344 & 0,118 & 0,183 \\
energi & $-0,005$ & 0,026 & $-0,225$ & 0,051 & 0,851 \\
$\begin{array}{l}\text { Asupan zat } \\
\text { besi }\end{array}$ & $-0,292$ & 0,04 & $-0,231$ & 0,053 & 0,808 \\
Motivasi & 8,252 & 73,6 & 0,894 & 0,80 & $0,000^{*}$ \\
\hline
\end{tabular}

Keterangan:

* = bermakna $p<0,05$ (uji statistik regresi linier ganda)

Berdasarkan Tabel 5 di atas dapat diketahui bahwa secara bersama-sama, hanya motivasi yang secara bermakna berpengaruh terhadap produktivitas. Sumbangan efektif untuk motivasi terhadap produktivitas adalah sebesar $73,6 \%$. Variabel motivasi merupakan variabel yang paling besar pengaruhnya dalam menentukan produktivitas.

Motivasi atau dorongan kepada karyawan untuk bersedia bekerjasama demi tercapainya tujuan bersama atau tujuan perusahaan terdapat dua macam yaitu: pertama, motivasi finansial yaitu dorongan yang dilakukan dengan memberikan imbalan finansial kepada karyawan. Imbalan tersebut sering disebut dengan insentif. Kedua motivasi non finansial yaitu dorongan yang diwujudkan tidak dalam bentuk finansial, akan tetapi berupa hal-hal seperti pujian, penghargaan, pendekatan manusiawi dan lain sebagainya (19).

Di Pabrik Bakpia Patuk 25, selain diberikan gaji pokok yang dibayarkan seminggu sekali juga diberikan insentif jika kerja lembur pada saat banyak pesanan. Selain itu, pada saat menerima gaji pokok, karyawan akan berhadapan langsung dengan pemilik pabrik. Kesempatan itu digunakan oleh pemilik untuk memberikan motivasi dan teguran pada karyawan bila kinerja karyawan dinilai rendah. Permasalahan-permasalahan yang menyangkut karyawan, baik yang berhubungan dengan pekerjaan atau masalah pribadi dapat diceritakan secara jelas sehingga pemilik pabrik mengetahui masalah yang melatarbelakangi kinerja karyawan yang tidak baik.

Pada dasarnya seseorang yang bekerja mengharapkan imbalan sesuai dengan jenis pekerjaannya. Karena adanya upah yang sesuai dengan jenis pekerjaan, maka akan timbul pula rasa gairah kerja yang semakin baik. Dengan terpenuhinya upah yang baik atau dengan kata lain upah yang tidak ditunda oleh para manajer/pimpinan, maka rasa kecukupan untuk memenuhi kebutuhan hidup, baik bagi dirinya sendiri maupun bagi keluarganya, akan dirasakan semakin terpenuhi. Selain itu, tenaga kerja akan merasa dibutuhkan oleh perusahaan dan tenaga kerja tersebut juga membutuhkan pekerjaan itu sehingga ada rasa timbal balik yang selaras (8).

Berdasarkan hasil analisis regresi linier ganda juga didapatkan bahwa produktivitas pekerja akan menurun sebesar 0,005 satuan jika asupan energinya meningkat $1 \mathrm{Kkal}$ dan produktivitas pekerja juga akan menurun jika asupan zat besinya meningkat $1 \mathrm{mg}$. Hal tersebut disebabkan pada saat melakukan recall untuk mengetahui asupan makan subjek, standar ukuran yang digunakan untuk membantu mengingat porsi makan subjek adalah dengan standar ukuran makan siang yang berada di perusahaan sehingga terdapat bias underestimate.

\section{KESIMPULAN DAN SARAN}

Berdasarkan hasil penelitian, maka dapat disimpulkan sebagai berikut: tidak ada hubungan yang bermakna antara asupan gizi (energi, protein, lemak, karbohidrat dan zat besi) dengan produktivitas kerja. Tidak ada hubungan yang bermakna antara status gizi dengan produktivitas kerja. Ada hubungan yang bermakna antara motivasi dengan produktivitas kerja. Secara bersama-sama, hanya motivasi yang memiliki hubungan yang bermakna dengan produktivitas kerja.

Dalam upaya peningkatan produktivitas pekerja, perlu diperhatikan menu dalam penyelenggaraan makan siang bagi karyawan yang sesuai dengan pedoman penyelenggaraan makan bagi karyawan, yaitu harus memenuhi $1 / 3$ dari kebutuhan zat gizi karyawan dalam sehari.

\section{RUJUKAN}

1. Sumbodo DP. Daya Saing dan Produktivitas Indonesia dan Negara-negara ASEAN. [serial online] 2007 [cited 2007 May 2]. Avalaible from: http://www.Apindo.or.id/ images/_rtes/produktivitasAseanDidik.

2. Anonim. Kesehatan bagi Pekerja Perempuan. [serial online] 2007 [cited 2007 April 13]. Avalaible from: URL: $\mathrm{http} / /$ :www.depkes.go.id.

3. Agus HZ. Anemia Gizi pada Perempuan Pekerja dan Penanggulangannya. Medika 2005; XXXI: 266-8.

4. Anonim. Kajian Kematian Ibu, Kematian Anak dan Status Gizi di Indonesia. [serial online] 2007 [cited 2007 Jul 3]. Avalaible from http://surkesnas.litbang.depkes. go.id.

5. Untoro JR, W Schultink, D Sediaoetama. The Assosiation Between BMI, Haemoglobin and Work Productivity Among Indonesian Female Factory Workers. Eur J Clin Nut 1996; 52:131-5.

6. Wolgemuth CJ et al. Worker Production of Kenyan Road Construction Labores. Am J Clin Nut 1982; 36:68-78. 
7. Kaeksi, R. Perbedaan Asupan Energi, Protein, dan Status Gizi Pada Kelompok Produktivitas Perajin Tempe Desa Lumbungrejo Kecamatan Tempel Kabupaten Sleman. [skripsi]. Universitas Gadjah Mada, Yogyakarta; 2005.

8. Anoraga P. Psikologi Kerja. Jakarta: PT Rineka Cipta; 2003.

9. Prasetyo E dan M Wahyudin. Pengaruh Kepuasan dan Motivasi Kerja Terhadap Produktivitas Kerja Karyawan Riyadi Palace Hotel di Surakarta. [serial online] 2008 [cited 2008 June 5]. Avalaible from: http: www.eeprint.ums.ac.id.

10. WHO. Obesity: Preventing and Managing the Global Epidemic WHO Technical Report Series 894. Geneva: WHO; 2000.

11. Lam SYW dan Conrad H.W Tang. Motivation of Survey Employees ini Construction Projects. Journal of Geospatial Engineering 2003; 5 (1): 61-6.

12. Latham CM. The Relation of Nutrition to Productivity and Well-being of Workers. [serial online] 2007 [cited 2007 Jul 3]. Avalaible from: http://www.zef.de/module/register/media tanggal 3 Mei 2007.

13. Martaniah SM et al. Laporan Penelitian HubunganAntara Tingkat Terpenuhinya Kebutuhan Fisik Minimal dan Produktivitas Kerja di Provinsi Jawa Tengah dan Sumatra Barat. Yogyakarta: Fakultas Psikologi UGM; 1990.
14. Rickum D, Arsiniati M Brata Arbai dan Kuntoro. Pengaruh Pemberian Makanan Tradisional Serwit Terhadap Produktivitas Kerja Karyawan. Prosiding Temu IImiah, Kongres XIII Persagi; 2005 437-48.

15. Weinberger K. Micronutrient Intake and Labor Productivity: Evidence from a Consumtion and Income Survey Among Indian Agricultural Labourers. Agriculture. 2004; 33 (4): 255-60.

16. Kennedy E, M Garcia. Body Mass Index and Economic Productivity [serial online] 2008 [cited 2008 Mart 17]. Avalaible from: www.unu.edu/ unupress/Fod2/IUDIUE/iudiue.htm.

17. Setyawati L. Kelelahan Kerja Kajian Terhadap Perasaan Kelelahan Kerja. [Disertasi]. Universitas Gadjah Mada, Yogyakarta; 1994.

18. Siagian PS. Kiat Meningkatkan Produktivitas Kerja. Jakarta: PT Rineka Cipta; 2002.

19. Daryatmi. Pengaruh Motivasi, Pengawasan dan Budaya Kerja Terhadap Produktivitas Kerja Karyawan Perusahaan Daerah Bank Perkreditan Rakyat Badan Kredit Desa Kabupaten Karang Anyar. [serial online] 2008 [cited 2008 June 5]. Avalaible from: www.eprint.ums.ac.id. 